\title{
UMOWA $^{1}$ \\ O WSPÓŁPRACY W DZIEDZINIE TURYSTYKI \\ MIĘDZY RZĄDEM PAŃSTWA IZRAeL \\ i RzĄDem Socjalistycznej Republiki Wietnamu \\ HANOI, 24 STYCZNiA 1996 R. ${ }^{2}$ \\ HTTPS://DOI.ORG/10.31743/SP.755
}

Rząd Państwa Izrael i Rząd Socjalistycznej Republiki Wietnamu, zwane dalej Umawiającymi się Stronami,

pragnąc umacniać przyjacielskie relacje oraz wzajemne zrozumienie pomiędzy obydwoma narodami,

podkreślając, że obydwa państwa są zainteresowane współpracą w dziedzinie turystyki,

mając świadomość, że turystyka stanowi ważny instrument poznania i wzajemnego zrozumienia pomiędzy obydwoma narodami, a także istotny element rozwoju ich stosunków gospodarczych,

uzgodniły, co następuje:

\section{Artykuł 1}

Umawiające się Strony będą rozwijać i umacniać współpracę w dziedzinie turystyki na zasadach wzajemności i obustronnych korzyści, zgodnie z prawem Umawiających się Stron.

\section{Artykuł 2}

Umawiające się Strony będą wspierać rozwój turystyki indywidualnej, jak również zorganizowanej turystyki grupowej, swoich obywateli oraz obywateli państw trzecich do Wietnamu i Izraela.

1 Materiał źródłowy został opracowany w ramach międzyuczelnianej współpracy pomiędzy Katedrą Prawa Międzynarodowego i Amerykańskiego Katolickiego Uniwersytetu Lubelskiego Jana Pawła II, Katedrą Prawa Międzynarodowego Publicznego Uniwersytetu Marii Curie-Skłodowskiej, Katedrą Prawa Międzynarodowego Uniwersytetu Szczecińskiego oraz Katedrą Prawa Międzynarodowego Publicznego i Prawa Europejskiego Uniwersytetu Śląskiego.

2 Agreement on tourism cooperation between the Government of the State of Israel and the Government of the Socialist Republic of Vietnam. Hanoi, 24th January 1996; tekst umowy w językach autentycznych angielskim, hebrajskim i wietnamskim (wraz z tłumaczeniem na j. francuski) został opublikowany w „United Nations Treaty Series”, t. 2620, nr I-46617, s. 203-217. Umowa weszła w życie w dniu 4 sierpnia 2000 r. 


\section{Artykuł 3}

Organem właściwym w sprawach realizacji postanowień niniejszej Umowy jest:

ze strony wietnamskiej:

ze strony izraelskiej:
Wietnamska Narodowa Agencja Turystyki Izraelskie Ministerstwo Turystyki.

\section{Artykuł 4}

Umawiające się Strony będą zachęcać do wymiany doświadczeń w sprawach związanych z organizacją, zarządzaniem i działalnością gospodarczą $\mathrm{w}$ dziedzinie turystyki oraz do wymiany publikacji i innych informacji o turystyce.

\section{Artykuł 5}

Umawiające się Strony będą dążyć do wspierania pomocy technicznej w dziedzinie turystyki poprzez wymianę ekspertów i szkolenie personelu. Wszelka pomoc techniczna, niezależnie od miejsca, w którym zostanie udzielona, oraz jej zasady i warunki, będą w każdym przypadku przedmiotem odrębnej umowy pomiędzy Umawiającymi się Stronami albo ich upoważnionymi organami wymienionymi w artykule 3.

\section{Artykuł 6}

Każda z Umawiających się Stron będzie sprzyjać i pomagać drugiej Stronie $\mathrm{w}$ powstawaniu narodowych biur turystycznych w swoim państwie w celu promowania turystyki.

\section{Artykuł 7}

Każda z Umawiających się Stron może zażądać w formie pisemnej, w drodze dyplomatycznej, zmiany niniejszej Umowy. Wszelkie zmiany, uzgodnione przez Umawiające się Strony, stają się wiążące w drodze tych samych procedur, co jej wejście w życie.

\section{Artykuł 8}

Wszelkie spory lub nieporozumienia dotyczące wykonania i stosowania niniejszej Umowy będą rozstrzygane polubownie w drodze konsultacji albo negocjacji przez Umawiające się Strony, wyłączając możliwość udziału stron trzecich bądź trybunału międzynarodowego.

\section{Artykuł 9}

Umowa niniejsza wejdzie $\mathrm{w}$ życie $\mathrm{w}$ dniu otrzymania ostatniego pisemnego powiadomienia, w którym Strony poinformują się wzajemnie 
o spełnieniu wewnętrznych wymogów prawnych niezbędnych do jej wejścia w życie.

Umowa niniejsza zawarta jest na okres pięciu lat. Umowa ulega automatycznemu przedłużeniu na dalsze pięcioletnie okresy, jeżeli żadna z Umawiających się Stron nie wypowie jej w drodze notyfikacji, w drodze dyplomatycznej, najpóźniej na sześć miesięcy przed upływem danego okresu ważności.

Sporządzono w Hanoi dnia 24 stycznia 1996 r. (co odpowiada Gimel Shevat, 5756 wg kalendarza żydowskiego), w dwóch egzemplarzach, każdy w językach hebrajskim, wietnamskim i angielskim, przy czym wszystkie teksty są jednakowo autentyczne. $W$ razie rozbieżności przy ich interpretacji tekst $\mathrm{w}$ języku angielskim będzie uważany za rozstrzygający.

tłum. Agata Szwed*

\footnotetext{
* Mgr, Uniwersytet Szczeciński.
} 
